\title{
特集 3
}

\section{レーザー 製 版 \\ 滝 本 靖 之*}

（1984年 7 月 3 日 受理）

\section{Laser Platemaking}

Yasuyuki TAKIMOTO*

(Received July 3, 1984)

\section{1. はじめに}

レーザー製版は光電変換によって読取られた 画像信号，コンピュターやスキャナーから出力 された画像信号あるいはファクシミリで伝送さ れた画像信号でレーザービームを変調させ，走 査機構を通じて印刷用版材にエネルギーを投入 し印刷用刷版を製作するプロセスである。主と して新聞印刷用刷版の製版に利用されている。
製作システムがどのように変るかを示したもの である。

レーザーを使用することの利点としては，高 エネルギーを微小スポットに集光でき, 高解像 度, 高密度記録が可能なこと, 変調, 偏光が容 易であること，指向性が高く光学的処理が比較 的容易であること，可干渉性であること，光モ ード記録，ヒートモード記録の両方が利用でき ることなどがあげられる。

Fig. 1 はレーザー製版の導入**によって新聞

(1)
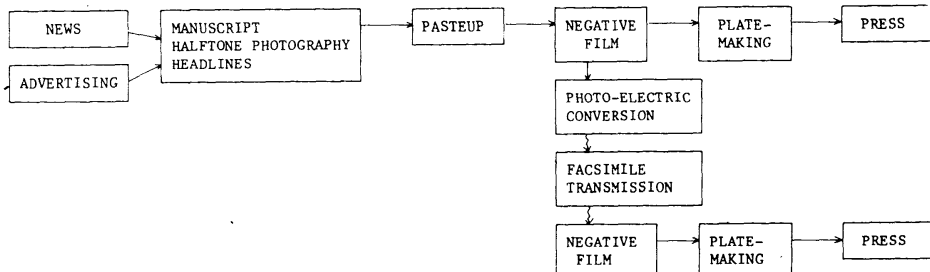

(2)

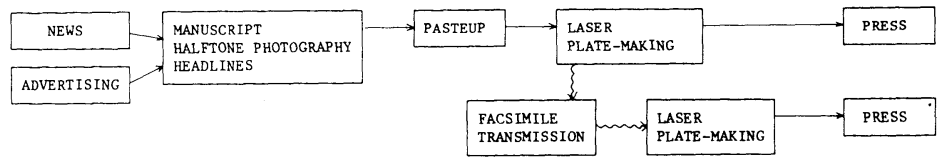

(3)

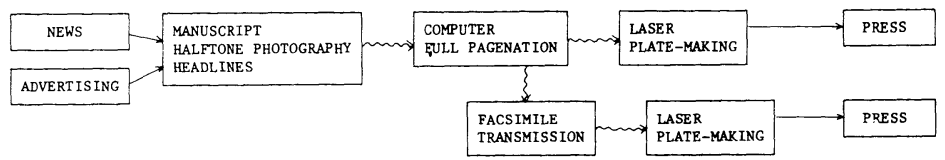

Fig. 1 Newspaper Production

*日本ペイント株式会社（テ572 寝屋川市池田中町19-17)

* Nippon Paint Co., Ltd. (Ikeda-Nakamachi, Neyagawa, Osaka 572)

** Fig. 1 中の(2)および3)に相当 


\section{2.レーザー製版システムの基本構成}

レーザー製版システムはレーザー光源，変調 器, 走查機構, 光学系および記録材料の 5 つの サブシステムから成立っている。その基本構成 をFig. 2 に示す。

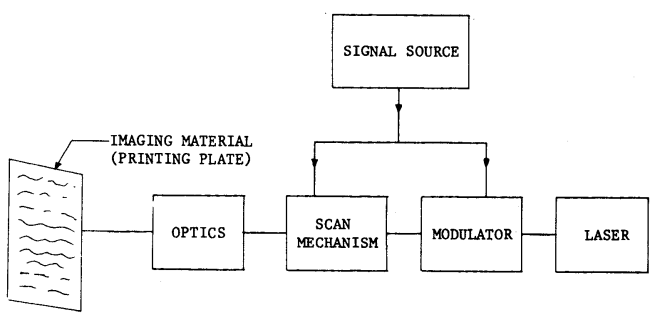

Fig. 2 Major laser scan subsystems

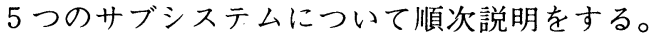

\section{3. レーザー光源の種類}

レーザー製版には，微小スポットに集光でき， かつ高いエネルギー密度が得られるレーザーが 適している。そのほか発振波長, 出力, 寿命な どもレーザー選択の上での重要な因子といえる。 レーザー製版装置に使用されている各種レー ザーの特性をTable I に示す ${ }^{1 !} 。$

\section{4. 変調器}

レーザービームを変調するためには, 音響光 学変調器 $(\mathrm{AOM})$ と電気光学変調器 $(\mathrm{EOM})$ が使 用できる。AOMと EOMの応答周波数を比べる

Table I Laser applicable to exposing graphic arts materials

\begin{tabular}{|c|c|c|c|c|c|c|}
\hline \multicolumn{2}{|l|}{ Laser } & \multirow{2}{*}{$\begin{array}{l}\text { Max. Output } \\
\text { Power (w) } \\
1-3\end{array}$} & \multicolumn{2}{|c|}{$\begin{array}{l}\text { Wavelenght } \\
\quad(\mathrm{mm})\end{array}$} & \multirow{2}{*}{$\begin{array}{l}\begin{array}{c}\text { Required Sensitivity } \\
\left(\mathrm{mJ} / \mathrm{cm}^{2}\right)\end{array} \\
5-15\end{array}$} & \multirow{2}{*}{$\begin{array}{l}\text { Chief Application } \\
\text { Conventional lithographic } \\
\text { plates and resists }\end{array}$} \\
\hline UV Argon & $(\mathrm{H})$ & & 357.1 , & 363.6 & & \\
\hline UV Argon & $(\mathrm{M})$ & $0.05-0.2$ & 357.1 , & 363.6 & $0.3-1.0$ & Film, paper \\
\hline VIS Argon & $(\mathrm{H})$ & $15-20$ & 488.0 & 514.5 & $80-100$ & $\begin{array}{l}\text { Scribing metallic films; } \\
\text { imaging plates with visible } \\
\text { sensitivity }\end{array}$ \\
\hline VIS Argon & $(\mathrm{M})$ & $0.2-5.0$ & 488.0 & 514.5 & $1-30$ & " \\
\hline VIS Argon & $(\mathrm{L})$ & $0.01-1.0$ & 488.0 & 514.5 & $0.05-0.5$ & $\begin{array}{l}\text { High speed electrophotographic } \\
\text { plates }\end{array}$ \\
\hline $\mathrm{He}-\mathrm{Ne}$ & $(\mathrm{L})$ & $0.001-0.01$ & 632.8 & & $0.005-0.05$ & $\begin{array}{l}\text { Functions as reading beam } \\
\text { in many systems; Exposure } \\
\text { of red-sensitive silver mati } \\
\text { materials }\end{array}$ \\
\hline UV Kripton & $(\mathrm{H})$ & $1-2$ & 406.7 & 473.1 & $5-10$ & $\begin{array}{l}\text { Conventional lithographic } \\
\text { plates, resists }\end{array}$ \\
\hline $\mathrm{He}-\mathrm{Cd}$ & $(\mathrm{L})$ & $0.005-0.05$ & 442.0 & & $0.03-0.3$ & $\begin{array}{l}\text { Blue sensitive silver materials } \\
\text { materials }\end{array}$ \\
\hline IR $\mathrm{CO}_{2}$ & $(\mathrm{H})$ & -100 & 10600.0 & & $200-2000$ & $\begin{array}{l}\text { Burning of flexographic } \\
\text { (rubber) printing plates }\end{array}$ \\
\hline \multicolumn{7}{|c|}{ Semi conductor } \\
\hline $\mathrm{Ga} \mathrm{Al} \mathrm{As}$ & $(\mathrm{L})$ & $0.001-0.015$ & $700-1300$ & & $0.005-0.08$ & \\
\hline IR YAG（M) & $(\mathrm{H})$ & $5-100$ & 1060.0 & & $30-600$ & $\begin{array}{l}\text { Vaporization or thermal } \\
\text { transfer of metal films or } \\
\text { plastic materials }\end{array}$ \\
\hline
\end{tabular}

(H): High powered laser

(M): Medium " "

(L): Low " " " 
Table II Modulator performance

\begin{tabular}{|c|c|c|c|c|c|}
\hline $\begin{array}{l}\text { Modulator } \\
\text { Type }\end{array}$ & Transmittance & $\begin{array}{l}\text { Frequency } \\
\text { Response }\end{array}$ & Rise Time & $\begin{array}{l}\text { Extinction } \\
\text { Ratio }\end{array}$ & $\begin{array}{l}\text { Power Handling } \\
\text { Capability }\end{array}$ \\
\hline $\begin{array}{l}\text { Electro-optic } \\
\text { (Visible light) }\end{array}$ & $70 \%$ & $\begin{array}{l}\text { Up- to } 50 \mathrm{MHz} \\
\text { limited by drive } \\
\text { electronics }\end{array}$ & $\begin{array}{l}5-15 n s e c \\
\text { er }\end{array}$ & $\begin{array}{c}160: \begin{array}{l}1 \text { at } \\
0 \\
4880 \mathrm{~A}\end{array}\end{array}$ & $5-6$ watts \\
\hline $\begin{array}{l}\text { Electro-optic } \\
\text { (UV light) }\end{array}$ & $60 \%$ & $\begin{array}{l}\text { UP to } 50 \mathrm{MHz} \text {; } \\
\text { limited by briver } \\
\text { electronics }\end{array}$ & $r^{5-15 n s e c}$ & $\begin{array}{l}20: 1 \text { at } \\
3511 / 3638\end{array}$ & $\begin{array}{l}<1 \text { watt; exact } \\
\text { limit undefined }\end{array}$ \\
\hline $\begin{array}{l}\text { Acousto-optic } \\
\text { (Visible) }\end{array}$ & $70 \%$ & $15-20 \mathrm{MHz}$ & $25 \mathrm{nsec}$ & $\begin{array}{l}\text { up to } 1000: 1 \\
\text { (deflected bea } \\
\text { beam) }\end{array}$ & $>20$ watts \\
\hline $\begin{array}{l}\text { Acousto--optic } \\
\text { (UV) }\end{array}$ & $60-70 \%$ & $15-20 \mathrm{MHz}$ & $25 \mathrm{nsec}$ & $\begin{array}{l}\text { Up to } 500: 1 \\
\text { (deflected } \\
\text { beam) }\end{array}$ & $>5$ watts \\
\hline
\end{tabular}

Table III Comparison of flatbed lasen scan system and drum scan system

\begin{tabular}{|c|c|c|c|c|}
\hline 項 & 目 & 平 & 面 & 筒 走 \\
\hline 構 & 造 & 機構部, & 電気回路ともに複雑 & $\begin{array}{l}\text { 平面走査に, 比べ簡単, 製造容易 } \\
\text { (精度的に) }\end{array}$ \\
\hline 有効画面サイ & ズ & 拡大にに & よ構造全体の変更が必要 & $\begin{array}{l}\text { 円筒交換, 光学系はそのままでよ } \\
\text { い }\end{array}$ \\
\hline 操 作 & 性 & $\begin{array}{l}\text { 優れてい } \\
\text { 性の良 }\end{array}$ & $\begin{array}{l}\text { つる。スキャナーは操作 } \\
\text { から平面走査の方向へ }\end{array}$ & 時間がかかる \\
\hline 自動化への適応 & & 良い & & 枚葉処理しかできない \\
\hline 記 録 ス ピー & ド & $\begin{array}{l}\text { スピー } \\
\text { 回転多 } \\
\text { れる。 }\end{array}$ & $\begin{array}{l}\text { がが上げにくい,ただし } \\
\text { 面鏡を採用すれば上げら }\end{array}$ & $\begin{array}{l}\text { 円筒内面走查で } 6000 \text { PPM が限度, } \\
\text { 複数走査線同時記録で高速化が可能 }\end{array}$ \\
\hline 像 & 力 & $800 \sim$ & $1,600 \mathrm{LPI}$ & アパーチャーが使える \\
\hline 光学系の効 & 率 & & $<25 \%$ & $>50 \%$ \\
\hline
\end{tabular}

と， $\mathrm{AOM}$ は15〜 $20 \mathrm{MHz}$ 程度であるが， $\mathrm{EOM}$ は50 $\mathrm{MHz}$ 程度まで可能である。しかし変調度 (消光比), 安定性などの面では $\mathrm{AOM}$ が優位に あるため, AOM（超音波周波数80〜 $140 \mathrm{MHz}$ ) が多く使用されている。

TableIlは, 変調器の特性を示したものであ $ろ^{2)}$ 。

変調方式を選択するにあたっては走査速度, フォーマット, 解像力および感光波長域なども 考慮することが必要なことはいうまでもない。 とくに消光比 $(\mathrm{QN}, \mathrm{OFF}$ 時の露光エネルギー の比率）は印刷紙面の白黒コントラストに影響
するので重視しなければならない。

\section{5. 走枯機構と光学系}

\section{1 走查機構}

走査方式には平面走査と円筒走査の 2 つの方 式がある。円筒走查では記録材料の装着方法の 差により，円筒外周走査 (External drum scanning）と円筒内面走查（Internal drum scanning）に分けられる。平面走査と円筒走査 の比較をTable IIII に示す。

読取り装置にあっては操作性のよい平面走査 方式が，書込み装置では次の印刷作業工程との 
兼合いで走査方式が選択されている。

\section{$5.2 f \theta$ レンズ}

平面走査方式では，ビームが記録面上に焦点 を結び，偏向角に対して等速運動を行わせなけ ればならない。そのためには偏向器と記録面の 間に強い樽型歪曲収差を示すフオーカシングレ ンズすなわち $f \theta$ レンズが使用されている。

\section{3 偏向系}

ビーム偏向には回転多面鏡 (rotating polygon), 回転多角錐鏡 (pyramidal spinner)，あるいは ガルバノメーターなどが使用されている。

偏向系の精度上の問題点としては, 平面走査 の場合は走査の直線性, 回転多面鏡の面精度, 割出し角度誤差, 倒れ角誤差, 円筒走査の場合 は回転の円滑さ，副走查方向の送り精度などが あげられる。

偏向系の精度不良は記録面上での記録位置誤 差を起させる。すなわち主走查方向ではジャダ 一, 副走査方向ではピッチむらとして記録され, 画像品質を低下させている3)。

\section{4 スポット}

記録面上でビームを小さなスポットに絞り込 むには，a）レーザーのビームを絞る，b)アパー チャー像を結像させる,の 2 つの方法がある。

Fig. 3 は焦点附近のビーム形状を示したもので ある。ビーム内のエネルギー密度 $P(r)$, 焦点 附近のビーム半径 $W z$, は(1)式および 2 式で表さ れる。

$$
\begin{aligned}
& P(r)=\frac{P_{0}}{\pi}\left(\frac{z}{W^{2}}\right) \exp \left(-\frac{z}{W^{2}} r^{2}\right) \\
& W_{z}^{2}=\left(1+\frac{\lambda^{2} Z^{2}}{\pi^{2} W_{f}^{4}}\right) W_{f}^{2}
\end{aligned}
$$

(2)式から最小ビーム半径は, $\lambda / \pi \theta$ で近似され， 小さなスポットを得ようとする場合は，いった んビームを拡大した後（ $\theta$ を大きくする）絞る ことが必要である。

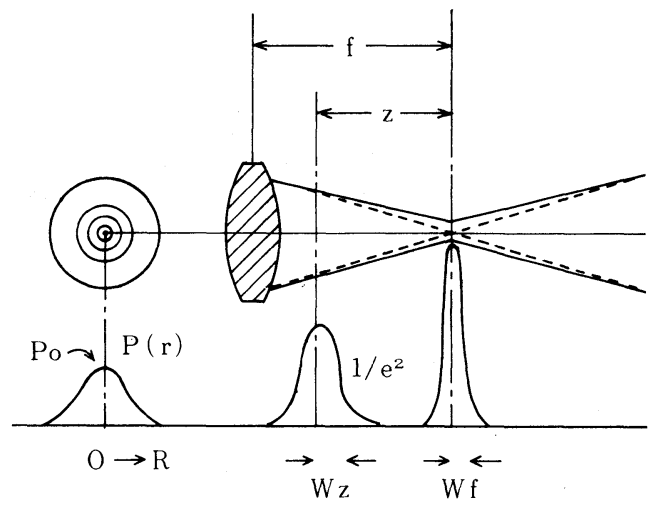

Fig. 3 Shape of laser beam near the focal point

\section{5 解像度}

レーザービームの集光度が解像度を決める大 きな要因になる。レンズで集光したビームスポ ットの直径 $a_{0}$ は(3)式で表される。

$$
a_{0}=1.27 f \lambda / D
$$

ここで $f$ は焦点距離， $D$ はレンズ径，入は波 長を表す。

たとえば, ヘリウムーネオンレーザー $(632.8 \mathrm{~nm})$ を用いる場合， $F=1$ とすると， $a_{0}=0.8 \mu \mathrm{m}$ に なり, $10^{8} \mathrm{bits} / \mathrm{cm}^{2}$ 以上の高密度記録が可能とな る。

\section{6. レーザー製版用材料}

レーザー製版材料は，単に記録だけを目的に するものでなく，平版用刷版としての機能*を 併せもつものでなければならない。

記録方法には材料の光化学反応を利用する光 モード記録と材料の熱現象を利用するヒートモ ード記録がある。高密度記録をするためにはフ

* 従来の平版刷版と同等の印刷適性を持っことが必 要である。すなわち画像部は親油性で平版インキに 対して適度の付着又レを示すこと。基板であるアル ミニウム板またはプラスチックフイルムに対する接 着力が強く, さらに耐水性や耐摩耗性がすぐれてい ること。 
オトポリマー系材料を光モードを走査露光させ るのがよい。ヒートモード記録は熱融着, 色素 の爇拡散のような即時，無処理記録が可能な材 料の画像形成に適しているが，光モード記録に 比べて, 高エネルギーを必要とし, 記録密度も 若干劣っている。

\section{1 レーザー製版用材料設計に際して考} 慮すべき因子

\section{1 .1 製版用材料の感度}

レーザービームのエネルギー強度のプロフイ ールはガウス関数で表される。中心のエネルギ 一強度を $I_{0}$ とすると, 中心から $r$ の点での強度 $I$ は(4)式で表される。

$$
I=I_{0} \exp \left\{-\left(r / a_{0}\right)^{2}\right\}
$$

ここで $a_{0}$ はエネルギー強度が中心の $1 / \mathrm{e}^{2} に$ なる点のビーム径を表す。

ヒートモード記録の場合は、レーザーが記録 材料層内で熱に転換されることが必要である。 一定体積 $v=\pi d\left(a_{0} /{ }_{2}\right)^{2}$ の記録材料層を $T{ }^{\circ} \mathrm{C}$ 昇温 させるのに必要なエネルギー $E_{\mathrm{T}}$ は(5)式で表され る4。

$$
E_{\mathrm{T}}=\pi d\left(a_{0} /{ }_{2}\right)^{2} C_{\nu} \cdot \Delta T
$$

ここで $C_{\nu}$ は体積熱容量で $10^{-2} \sim 10^{-3} \mathrm{~nJ} /\left(\mu \mathrm{m}^{3}\right.$. $\left.{ }^{\circ} \mathrm{C}\right) \Delta T$ は記録に必要な昇温巾, $d$ は記録材料 層の厚さを表す。

高密度記録を行う場合, ビットが小さくなる につれて $\Delta T$ は小さくなる。多くの熱記録材料 の場合, 体積が $1 \mu \mathrm{m}^{3}$ 程度であれば $\Delta T$ は最高 でも $100{ }^{\circ} \mathrm{C}$ 程度である。したがってビットあた

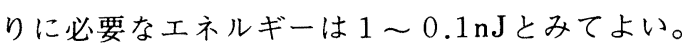
記録速度が10Mビット/秒とすれば，レーザー 出力は $1 \mathrm{~mW}$ が必要ということになる。

光モードで記録する場合のレーザー出力, 走 查速度と記録材料に必要な感度の関係は, (6)式 で表される゙”。

$$
S=\frac{60 \cdot l \cdot p \cdot \alpha \cdot \Sigma}{(2.54)^{2} \cdot w \cdot l \cdot v}
$$

ここで $S$ は記録材料に必要な感度 $\left(\mathrm{mJ} / \mathrm{cm}^{2}\right)$ $p$ はレーザー出力 $(\mathrm{mW})$

$\alpha$ は光学系の効率*

$\Sigma$ は走查効率

$w$ は走查巾 (インチ)

$l$ は走査長（インチ）

$v$ は走查速度 (インチ/分)

たとえば大きさが $15 \times 22$ インチの新聞 1 ペー ジを紫外線出力 2.5 Wのアルゴンレーザーで 2 分間で走査露光する**には, $\alpha=0.25, \Sigma=0.5$ とした場合, 記録材料に必要な感度は $17.5 \mathrm{~mJ} / \mathrm{cm}^{2}$ になる。ちなみに現在使用されている平版版機

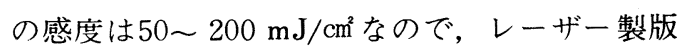
に使用するためには相当に高感度の製版材料が 必要になる。だ足ではあるが可視光出力 $18 \mathrm{~W} の$ アルゴンレーザーであれば必要な感度は $126.8 \mathrm{~mJ} / \mathrm{cm}^{2}$ になり，紫外部より 7.2 倍低感度のものでも 2 分間で走查露光できることになる。

レーザー出力と記録材料に必要な感度の関係 を示すとFig. 4 のようになる。

記録材料の感度が下がると, 走査露光に要す る出力を増やさなければならないことを示して いる。

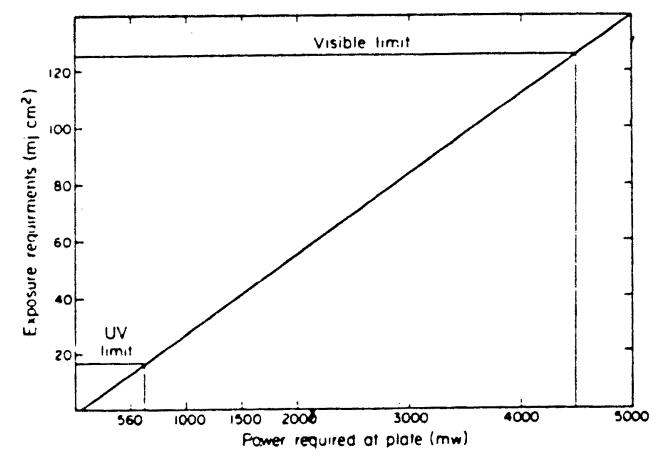

Fig. 4 Requirements for a "Two-minute" plate

*ガスレーザ一, 変調器, レンズ系を使った炕学 系の効率 $\alpha$ は25〜30\%であるが, 半導体レーザー を直接変調する場合，効率 $\alpha$ は55 60\%にもなる。

* Two-minute plate, 実用化の一応の目安として 設定された走査時間 
各種のレーザーを光源とする場合の記録材料 に必要な感度 $\left(\mathrm{mJ} / \mathrm{cm}^{2}\right)$ をTable I に示す。

\section{1 .2 相反則}

記録に必要な光量 $E(E=I \cdot t)$ が光強度 $I$ の 変化に関係なく一定の場合, 記録材料層の光に よる変化量 $D$ (たとえばゲル分率) は $D=f(I, t)$ で表される。この場合は相反則が成立している。 一方 $E$ が一定でも $I$ の変化によって $D$ が異る場 合は，相反則不軌が生ずるといわれる。実用的 なレーザー走査速度でのスポットあたりの露光 時間は $1 \sim 0.5 \mu \mathrm{sec}$ のような短時間であり， かつ高照度露光であるため, 従来の水銀灯露光 とは条件がかなり異なっている。したがって材 料の選択にあたっては，高照度域での相反則を 確かめることが必要である。なお光強度 $I$ と露 光時間（走査速度）の関係をプロットすること で相反則挙動を知ることができる。

\section{2 光モード記録用製版材料}

フォトポリマーを利用するものと, 電子写真 方式を利用するものの 2 つに分けられる。

\subsection{1 フォトポリマーを利用する製版材料}

i ) 光橋カケ型ポリマー

光橋カケ型ポリマーは通常短波長感光性（主 として紫外線）であるが, 三重項増感夙を使用 すると可視域まで増感できる。三重項増感郕で 増感したポリマー系はレーザーに対して十分な 感度を持つようにみえても, 走査速度が大きく なり, 露光時間がたとえば $40 \mu \mathrm{sec}$ 以下のように 短かくなると相反則不軌が生じ, 急速な感度低 下が認められるようになる。実用的な走査速度 でのスポットあたりの露光時間 $1 \sim 0.5 \mu \mathrm{sec}$ は記録不能になることがある。その理由として は, 三重項増感では三重項エネルギーの移動の 速度が光による変化（感光）の律速になるため と考えられる。したがって高速の走査露光に使 用する製版材料には相反則不軌が生じない増感 系あるいは可視光で直接反応する系を見つける ことが必要である。研究事例は文献6)を参照さ
れたい。

ii）光重合型ポリマー

光ラジカル重合型ポリマーは可視光域に感度 をもつ光重合開始剤を使用することで, 可視レ 一ザー記録ができるようになる。光重合開始剤 の励起によって直接ラジカルが生成する系では, 高照度，短時間露光域まで相反則不軌が起らな い。研究事例は文献 ${ }^{6)}$ 参照されたい。

\subsection{2 電子写真方式を利用する製版材料 ${ }^{7)}$}

トナー層をレジストおよびインキ付着層とし て利用する CPC 方式の製版方法である。製版 材料は陽極酸化アルミニウム板上に有機導電体 ( OPC) が $5 \mu \mathrm{m}$ 程度の厚さに塗布されたもので ある。コロナ帯電後, 像露光をして, 磁気ブラ ッシまたは湿式現像でトナー画像を形成させる。 非画線部の OPC 層をアルカリ溶液で除去し, アルミニウム面を露出させて平版刷版とし.て使 用する(Elfasol, Kalle)。OPC として銅フタロ シア二粒子とノボラック樹脂からなる分散層を 使用した平版刷版もある(Direxer, 小西六)。 トナーの極性を変えることでネガ原稿からポジ 画像を作ることができる。

$\mathrm{OPC}$ の代りに $\mathrm{ZnO}$ を使用し, 画像部はトナ ープラス $\mathrm{ZnO}$, 非画線部は $\mathrm{ZnO}$ である平版刷 版も知られている(News-plater, Chemco).

光モード記録が可能な平版版材の一例を Table IV に示す。

Table IV Exposure requirement of the laser sensitive lithographic plate

\begin{tabular}{|c|c|c|}
\hline Supplier & Plate Type & $\begin{array}{c}\text { Exposure Requirement } \\
\left(\mathrm{mJ} / \mathrm{cm}^{2}\right)\end{array}$ \\
\hline Howson Algraphy & Presensitized & $8-10 /$ uv argon (H) \\
\hline Howson Algraphy & Presensitized & $4-5 / v$ is argon (M) \\
\hline Kalle/Azoplate & Presensitized & $8-10 /$ uv argon $(\mathrm{H})$ \\
\hline Kalle/Azoplate & Presensitized & $0.02 / \mathrm{vis}$ argon (L) (EF) \\
\hline Richardson & Presensitized & $8-10 /$ uv argon $(\mathrm{H})$ \\
\hline Western Litho & Presensitized & $7-10 /$ uv argon $(\mathrm{H})$ \\
\hline Western Litho & Wipe-on & $10-20 /$ uv $\operatorname{argon}(\mathrm{H})$ \\
\hline Western Litho & $\begin{array}{l}\text { Wipe-on } \\
\text { two-coat }\end{array}$ & \\
\hline Fuji Chemical & Presensitized & $15-30 / v$ is argon $(\mathrm{M})$ \\
\hline Anocoil & $\begin{array}{l}\text { Wipe-on/ } \\
\text { Presensitized }\end{array}$ & $3-5 /$ uv argon $(\mathrm{H})$ \\
\hline Advance & $\begin{array}{l}\text { Wipe-on/ } \\
\text { two-coat }\end{array}$ & $5-10 /$ uv argon $(\mathrm{H})$ \\
\hline $3 \mathrm{M}$ & $\begin{array}{l}\text { Wipe-on/ } \\
\text { special } \\
\text { Process }\end{array}$ & $3-5 /$ uv argon $(\mathrm{H})$ \\
\hline Lith- Kem-Ko & Wipe-on & $8-15 /$ uv argon $(\mathrm{H})$ \\
\hline $\begin{array}{l}\text { International Litho } \\
\text { James River }\end{array}$ & $\begin{array}{l}\text { Wipe-on } \\
\text { Presensitized }\end{array}$ & $\begin{array}{l}7-12 / \text { uv argon }(H) \\
0.03 / v \text { is argon }(L)(E F) .\end{array}$ \\
\hline $\begin{array}{l}\text { James River } \\
\text { (Chemco) }\end{array}$ & Presensitized & \\
\hline Fuji Phato Film & Presensitized & $0.008 / v i s$ argon (L) \\
\hline
\end{tabular}

(EF): Electrostatic Plate using $\mathrm{ZnO}$ or OPC 
6.3 ヒートモード記録用製版材料

レーザービームによって記録材料層の色材を リセプター上に転写させるいわゆるレーザート ランスファーと呼ばれる記録方法が応用されて いる。感熱性の高分子バインダーに黒鉛を分散 させた樹脂液が塗布されている非感光性フイル ムを，表面を親水処理したアルミニウム板に密 着させる。アルゴンまたはYAGレーザーで走 査記録すると，画像部にあたる黒色記録層がア ルミニウム板に溶融転写されると同時にネガフ イルムが得られる。画線部が転写されたアルミ ニウム板は加熱処理をすると平版刷版として使 用できる。感度は $100 \mathrm{~mJ} / \mathrm{cm}^{2}$ である ${ }^{8)}(\mathrm{Laser}$

Mask, Log Etronics)。

\section{7.レーザー製版装置}

レーザー製版装置は1965年頃からアメリカで 研究が始められた。その当時ははレーザー出力 が小さく，また種類も限られていたため，探索 研究の域を出来なかった。その後10年余りの間 にレーザーおよび関連材料の発達, 光化学的お よび物理的画像形成技術の発展にともなって, システム上の問題点が漸次解決され，1974年か ら1975年にかけて相次いで商品発表が行われた。

実用化されているレーザー製版システムの概 要を述べる9)。

7.1.レーザーライト(Laserite, Eocon Electronic Systems)

レーザーライトはFig. 5 に示したように，読 取りと書込みに共通の回転多角錐鏡を使用する 平面走査式の装置である。

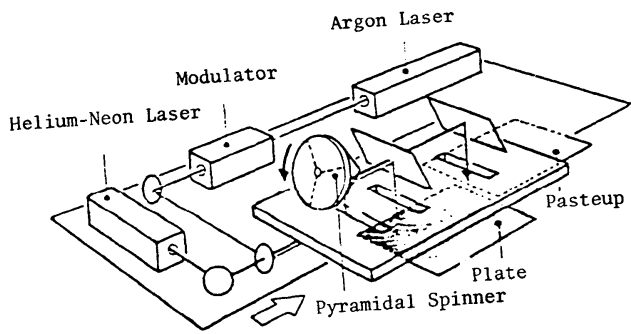

Fig. 5 Laserite system
ヘリウムーネオンレーザーで原稿を走査して 読取り，アルゴンレーザー $(488.0,514.5 \mathrm{~nm})$ で刷版あるいはリスフイルム上に走査露光して 書込ませる。アルゴンレーザーの出力を選択す ることで, 感度 $5-10 \mathrm{~mJ} / \mathrm{cm}^{2}$ の平版刷版から $10^{-2} \sim 10^{-3} \mathrm{~mJ} / \mathrm{cm}^{2}$ の電子写真刷版まで製版でき る。走査解像力はインチあたり 1,000 本, スク リーン解像力はインチあたり 100 線, 製版速度 は時間あたり55版である。

\section{2 ログイスキヤン ( Log Escian, Log} Etronics Inc.)

Fig. 6 に示したように静止ドラム・回転ビー 厶走查式の装置で，原稿（新聞 2 ページ分）を 静止した円筒内面に取りつけて，へリウム一ネ オンレーザーで走查し, インチあたり 800 1,000本で読取る。

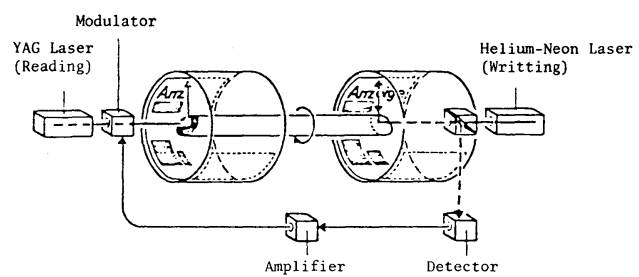

Fig. 6 Log Escan system

YAGレーザー（主波長は 1,060nm の近赤外 光)でアルミニウム板に密着させたLaser mask に書込む。製版スピードは時間あたり40版，ス クリーン解像力はインチあたり 100 線である。

\section{3 レーザーページファクス( Laser Page}

Fax/Plate System, Muirhead, Inc.)

Fig. 7 に示したようにへリウムーネオンレー ザーを用いる読取り装置と，アルゴンレーザー を用いる書込み装置に分かれている。

それぞれの装置の走査方式には平面走查と円 筒走查があり，任意の組合せができるが，一般 には平面走査一平面走査の組合せが使用されて いる。 


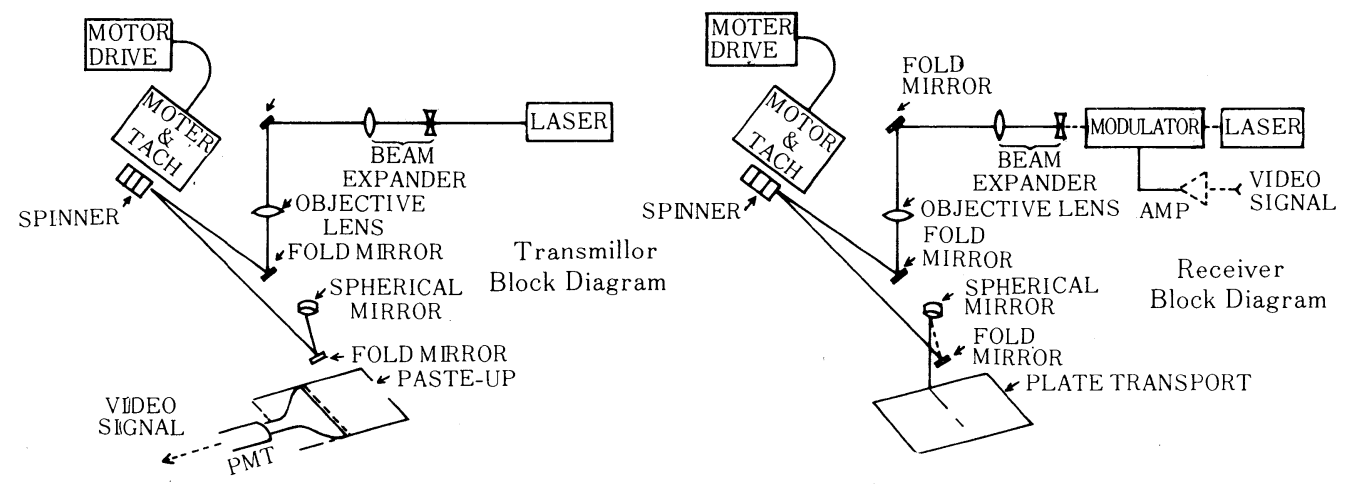

Fig. 7 Muirhead laser pagefax/plate system.

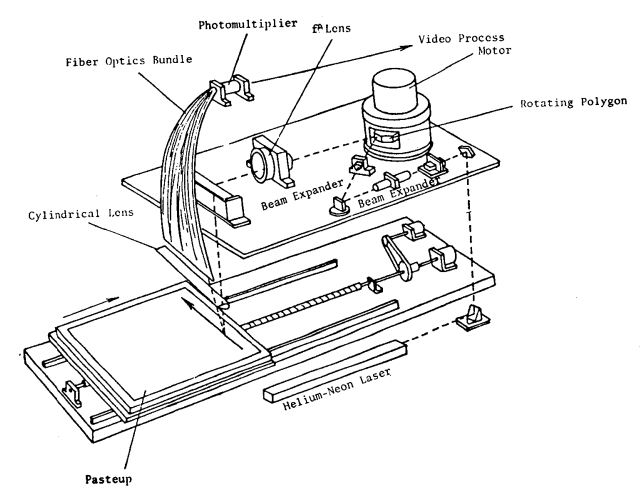

Fig. 8 Asahi-Shimbun laser system(transmitter)

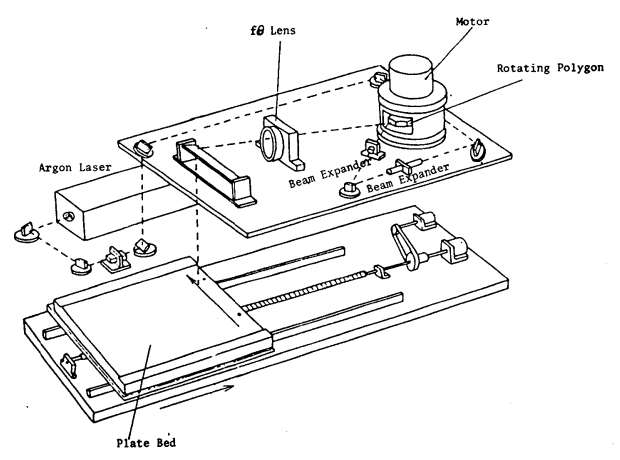

Fig. 9 Asahi-Shimbun laser system( receiver)

7.4 朝日新聞社のレーザーシステム ${ }^{101}$

(朝日新聞社一松下電送一日本電気の共同開発) 読取り装置(Fig. 8 ) と書込み装置 (Fig. 9 ) に分かれており, 平面走査方式でファクシミリ を兼ねている。
7. 5 レーザーダイレクサー( Laser Direxer, 小西六)

書込み装置にヘリウムーネオンレーザーを使 用した平面走査方式で, 電子写真刷版の製版に 用いられる。

\section{8. まとめ}

1.レーザー製版はレーザーを用いて原稿か ら直接印刷用刷版を製作するプロセスであ り, 主として新聞印刷用刷版の製版に利用 されている。

2.レーザー製版システムは, レーザー光源, 変調器, 走査機構, 光学系および記録材料 の 5 つのサブシステムから成立っている。 これらのサブシステムで特記すべきことは

a) レーザー光源は, 光エネルギーを微小ス ポットに集光でき, 高解像度, 高密度記録 ができるレーザーすなわちへリウムーネオ ンやアルゴンレーザーが適している。

b) 変調器は変調度 (消光比), 安定性より みて音響光学変調器 $(\mathrm{AOM})$ が適している。

c）走査機構では平面走査方式が操作性の面 からみて優位にある。

d）記録材料は光モード記録材料とヒートモ 一ド記録材料に分けられる。微小スポット あたりの走査露光時間は $1 \sim 0.5 \mu \mathrm{sec} の よ$ うに極めて短時間であるため, 記録材料は いづれの場合も高感度でなければならない。 
高感度化によって大型レーザー装置が必要 でなくなり，管の寿命や消費電力など経済 性の面で実用化の阻害要因を取除くことが できる。

3. 光モード記録に使用されるフォトポリマ 一系記録材料は, 感度 $1 \sim 10 \mathrm{~mJ} / \mathrm{cm}^{2} の も の$ が実用化されている。感度を上げる研究を 行うにあたっては, 高照度, 短時間露光の もとで相反則不軌を起さない系を探索する ことが必要である。

4.ヒートモード記録は光モード記録に比べ て高エネルギーを必要とし, 記録密度も若 干劣っている。

\section{参考文 献}

1) S. T. Dinn: TAGA Proceedings (1980) 279.

2) R. E. Amtower: The Photoplatemakers Bulletin 5 (1977) 4.

3) 梶光雄; 日.本印刷学会 82 夏期セミナー講演要旨 (1982) 20

4) Di Chen : Proceedings of The IEEE 63 No. 8 (1975) 1207.

5) S. Kaplan: TAGA Proceedings (1977) 90.

6) 山岡亜夫; $82 / 3$ 高分子可能性講演要旨集 (1982) 46 .

7) 高橋恭介：印刷雑誌65No. 2 (1982) 11.

8) R. M. Landsman: TAGA Proceedings (1977) 1.

9）日本新聞協会：新聞技術情報14 No.17（1982） 5 .

10）永松元太郎：画像電子学会誌 9 （1980） 79. 